\title{
FATHOM
}

\section{The Hermeneutics of Compassion: The Case of}

Fanny Robin

Herméneutique de la compassion: le cas de Fanny Robin

\section{Rosemarie Morgan}

\section{(2) OpenEdition}

\section{Journals}

\section{Electronic version}

URL: http://journals.openedition.org/fathom/557

DOI: 10.4000/fathom.557

ISSN: 2270-6798

\section{Publisher}

Association française sur les études sur Thomas Hardy

\section{Electronic reference}

Rosemarie Morgan, «The Hermeneutics of Compassion: The Case of Fanny Robin », FATHOM [Online], 3 | 2016, Online since 30 April 2016, connection on 20 April 2019. URL : http:// journals.openedition.org/fathom/557; DOI : 10.4000/fathom.557

This text was automatically generated on 20 April 2019. 


\title{
The Hermeneutics of Compassion: The Case of Fanny Robin
}

\author{
Herméneutique de la compassion: le cas de Fanny Robin
}

\section{Rosemarie Morgan}

\begin{abstract}
We must build a bridge between contemplation and action [...]. Compassion without action is [...] hypocritical [...] we must act each time we can and, even more, try to prevent suffering before it starts.

Our own happiness is intimately linked to that of others. Most of our problems derive from the fact that we are not genuinely concerned with other people's well-being. Any happiness we feel that ignores others' unhappiness, or, even worse, bases

itself on their suffering, can only ever be a pale imitation of happiness [...] someone who has reached enlightenment spontaneously feels boundless compassion for others. (Ricard \& Thuan
\end{abstract}

258-260)

1 As editor of the Cornhill in the 1870s Leslie Stephen had commissioned the publication of Far From the Madding Crowd (1874), unaware at the outset that it would shortly arouse his deepest concerns of censorship. He eagerly examined Hardy's first few chapters as they arrived on his desk for the opening instalment and detected no sign of indiscretion, no hint of transgression of any kind, nothing that might violate his puritanical ethic and the middle-class "family values" of the Cornhill readership. Far From the Madding Crowd was, to all intents and purposes, a pastoral romance along the lines, as requested by Stephen, of Under the Greenwood Tree featuring a winsome Milkmaid, a Good Shepherd and a Dashing Young Sergeant with a "winning tongue".

2 However, as the second instalment begins to take shape the narrator, in an unanticipated volte-face, steers an alternative course: quite out of the blue a benevolent landowning 
uncle (Everdene) entrusts his farming estate to his highly-respected niece who had recently shown strong signs of competence and good management and in a flash Bathsheba Everdene (hitherto the "Winsome Milkmaid") turns farmer and estate manager overnight. At the same time, an inexperienced young sheepdog in hormonal disarray, excited with bloodlust at the hands of his master who, carelessly, feeds him the carcase of a dead newborn lamb, drives Oak's entire flock over a cliff thus reducing the "Good Shepherd" to penury - again, overnight. He is now a homeless, itinerant labourer. The "pastoral romance" is over: the drama begins.

3 This brief exegetical study ventures into certain matters which Hardy's publishers chose to shield from his readers. As his letters reveal, by the time the second instalment of Far From the Madding Crowd arrives on the editorial desk Leslie Stephen is paying close attention to the manuscript sections he is now receiving. To begin with the first alert, Fanny Robin, who had not, initially, been mentioned anywhere at all in Hardy's proposal, now enters the scene. Innocuous enough as it appears at the outset Fanny's role had not only been omitted from Hardy's plot outline but there had been no suggestion of a wayward runaway girl, nor her seduction and certainly no forewarning that these events would culminate in a tragic exposition of a young, unwed mother's death in childbirth.

Indeterminate "hints" there are now, however, for the attentive reader of these early chapters as Fanny Robin, albeit clandestinely, emerges to take her place in the plot proper. For all his narrow-minded prudery Stephen was a skilled and sensitive editor and it might well have occurred to him that such an unforeseen diversion as the unexpected emergence of Fanny at this point should prompt his vigilance; perhaps things are not quite what they seem? Is Fanny's story really just a simple subplot? For indeed, a prelusive subversiveness in Far From the Madding Crowd is discernible as early as this moment in the second instalment. A circumspect editor might be worried.

Embedded in what I have called the hermeneutics of compassion it is the textual activation of this subversive narratorial stance and its significance as embodied in Hardy's original characterisation of Fanny Robin that this essay will explore. The reader's first encounter with Fanny occurs very early on, immediately after the fire that almost destroys Bathsheba's hay ricks in the chapter entitled "A Timid Girl." It is not, however, a "Timid Girl" who first comes into view. The narrator is engaged elsewhere - still attending to Bathsheba who is now withdrawing from Gabriel Oak's discomfiting gaze (a withdrawal she is obliged to perform, frequently), just after he has surprised her with the question, "Do you want a shepherd ma'am?" Taken aback but immediately distancing herself by retreating out of view, into the shade, Bathsheba replies, "I do want a shepherd. But - " (Hardy 43).

6 In hermeneutic terms, Bathsheba's withdrawal and broken utterance provides the first of several linguistic indicators called aposiopesis ${ }^{1}$ that will shortly cluster around the "Timid Girl's" arrival on the scene. "But - " - such a tiny particle of speech - not only sets inclination, or desideratum ("want") at odds with itself but also disconnects the two speakers, Bathsheba and Oak, one from the other. Perceiving this, noticing the break in the proceedings, the bystanders, the local field workers, are roused to intervene and start to clamour in Oak's favour.

7 An alternative linguistic term to aposiopesis, the narratorial disconnect where an utterance is silenced, where a phrase is deliberately broken off, is the "collapsing sequence". Collapsing sequences occur when utterances between speakers elide unspoken thoughts, the implication being that a logical thought has occurred between the spoken 
thoughts. For instance, in this case, Oak wants and Bathsheba wants but no sooner has she said it than she cuts off the thought with "But -". The unspoken thought is left to the reader's imagination but no doubt Oak knows exactly what is running through her mind: "Good grief! And this is the man who asked to marry me a few weeks ago?"

There is of course the simple logistical consideration here of plot mechanics; that is, without the disconnect between the speakers the fire-fighting bystanders might never intervene to secure Oak's employment as shepherd on Bathsheba's estate. Thus, this one tiny particle of speech - "But" - performs quite a large amount of work. Why, though, do I draw attention to it? Not solely for what it says about Bathsheba's budding relationship with Oak (which will become, as we know, one long series of uncomfortable disconnections and niggling doubts, misgivings, embarrassments, incoherent thoughts and feelings), but also for what it tells us about Hardy's preparatory schema for the "Timid Girl" who now appears out of the darkness just as Bathsheba disappears into it. To be sure, Bathsheba will eventually be "broken" emotionally, psychologically, by the various coercive manipulations of the men who pursue her, including Gabriel Oak; more to the point here, it is Fanny Robin who - precursively - arrives on the scene, broken. In a literal sense her life has broken up - she is destitute, homeless and pregnant - and in a regenerative, if not altogether prophetic sense this child-woman is no longer sexually intact. That synecdoche of female sexual autonomy, the hymen vaginae, has also been broken by the paternalis of her unborn child. "Broken" is of course just a few linguistic degrees of separation from "Fallen".

If Fanny's young life is, at this point, broken up, in less than a year it will be completely over. Or - as the narrator recounts of the child-mother, some six moons later, in the tragic coffin scene:

The mother had been no further advanced in womanliness than had the infant in childhood; they both had stood upon the threshhold [sic] of a new stage of existence, and had vanished before they could well be defined as examples of that stage. (Hardy 259-260)

Notice, incidentally, how the stern rhetoric attempts to harden any softness, any tenderness that might be too apparent in the narrator's rising compassion; the rhetoric restrains the narrative stance and adds perturbation to the gaze which lingers upon the budding young girl in her coffin; a mother yet scarcely a woman on the very threshold of a new life with a stillborn babe in her arms. The emotional pull of the speaker's compassion is almost palpable yet stilled. Certainly there is no excessive sentiment. For, the hazard here, as in any moving sequence of tragical dimensions, is that the speaker's vision and in turn the narration itself, could collapse into melodrama or maudlin sentimentality risking a further lapse into mere linguistic gestures that could all too easily come across as mawkish and insincere.

11 Simultaneously, compassion for the "transgressive" girl should at best, for reasons of publication politics and market-decorum, be filtered through a secondary character, preferably a weak or unreliable character; failing that, no sympathetic identification with Fanny should resound in the overt voice of the primary narrator who, seemingly lacking all inclination to adopt the judgemental role of censor risks accusations of partiality - an unreliable witness acting in cohorts with the transgressor ${ }^{2}$. Quite a challenging task for the young author struggling to learn how to be a "good hand at a serial".

12 Thus, no sooner has the impact of girl-mother and stillborn babe stricken pitifully upon the senses than a forbidding rhetoric tainted with magisterial pomposity insists on 
battening down all sympathetic responses, concluding with: "they both had stood upon the threshold of a new stage of existence, and had vanished before they could well be defined as examples of that stage" (Hardy 259-260). Notice that in one short statement, adopting the confident stance of one who expects to be obeyed, the speaker moves from one sterile utterance, stage of existence ${ }^{3}$ to another, defined, a harsh transitive verb literally denoting the setting of boundaries (a significant word choice), then finally to choose yet another cold Latinate word, example (Latin: exemplum). Thus, the summoning of this austere voice, which endeavours to articulate a chilling set of verbal gestures sufficiently overbearing to stem any flow of emotional response, seeks to harden compassion in the listener's heart, notably that of the ultimate judge, editor Leslie Stephen.

However, to the oblivious tender heart, oblivious to the dictatorial judge who speaks beyond her ken, there are only the choking tears - the tears that Bathsheba, herself, cannot hold back.

Her head sank upon her bosom, and the breath which had been bated in suspense, curiosity and interest, was exhaled now in the form of a whispered wail: "Oh-h-h!" Her tears fell fast beside the unconscious pair - tears of a complicated origin, of a nature indescribable, almost indefinable except as other than those of simple sorrow. (Hardy 260)

But this is, in fact, the manuscript version and no amount of stern rhetoric worked its surreptitious way into the heart of the vigilant Stephen. He instantly saw through Hardy's artful devices and censored the coffin scene quite ruthlessly. He cut the entire sequence.

The volume edition ${ }^{4}$ repairs some of Stephen's cuts but, to give just one example of Hardy's difficulty in recapturing the original I would cite the "whispered wail" in the manuscript which later becomes, "and the silent room added length to her moan". This has the effect of externalising Bathsheba's inner pain. Whereas the manuscript version halts at the point of her "whispered wail" leaving her cry to ring, resoundingly, in our ears ${ }^{5}$, the reparative volume edition turns the lens on to the silent room and shifts the woman's agony to the outside world - the room not only absorbs her pain but turns it into a sound effect merely. Alas, for Hardy, "recapture" in this instance is not a question of retaking but of being retaken.

The irremediable problem for Hardy in revising Far From the Madding Crowd for the volume edition and all post-Cornhill editions was that he didn't have his original manuscript to hand. It was believed lost at that time. How difficult, indeed how distressing it must have been trying to relive his first creation, reviving imaginative percepts of objects formerly given in sense perception, composed in the very first flush of writing, re-created at great speed, no less; recalling painful episodes must have been even more problematic ${ }^{6}$. This whole process would surely have been further complicated by having been so severely censured by editor Stephen in the first instance. Once, later in life, Hardy reflected that censorship was paralyzing. This touches only the tip of the psychological "iceberg" so to speak: the censured Hardy, in revision, is not only working in an altered state of consciousness but is also compelled to exert memory over imagination. I would argue that in attempting to revive his original creation for the volume edition and in making late revisions of this kind - turning Bathsheba's agonized cry, for example, into a mere sound effect - reflects just such a paralysis.

17 I'll be returning to the coffin episode again shortly - but first let's complete the exegetical investigation into the reader's first encounter with "The Timid Girl" - Fanny Robin. Gabriel Oak is now walking into the darkness on his way to the Malthouse to seek lodging 
for the night when he accidentally meets Fanny, for the very first time, in the village churchyard, an appropriate setting for a first encounter with this destitute young girl but also ironic in that consecrated ground is precisely what is later denied her, as a "Fallen" woman. Fanny will be buried in the pauper's section of that selfsame Weatherbury churchyard: "a spot which until lately had been abandoned to heaps of stones and bushes of alder" (Hardy 273) $)^{7}$. A "spot", moreover, which will all too soon become flooded as the downpour of rain gushes off the church roof to be jettisoned through the spouting jaws of the gargoyle on to Fanny's grave washing away every vestige of flower, shrub and blossom that Troy had planted there.

18 I think it's worth pausing over Hardy's vivid description of the church gargoyle; I should add that I am making trips between these early and late passages for good reason: they provide parallel intersections within the narrative.

Weatherbury tower was a somewhat early instance of the use of an ornamental parapet in parishes - as distinct from cathedral churches, and the gurgoyles, which are the necessary correlatives of a parapet were exceptionally prominent - of the boldest cut that the hand could shape, and of the most original design that a human brain could conceive. There was that symmetry in their distortion, so to speak, which is less the characteristic of British than of Continental grotesques of the period, though all four were different from each other. A beholder was convinced that nothing could be more hideous than those he saw on the south side - until he went round to the north. Of the two on this latter face, only that at the northeastern corner concerns the story. It was too human to be called like a dragon, too impish to be like a man, too animal to be like a fiend, and not enough like a bird to be called a griffin. This horrible stone entity was fashioned as if covered with a wrinkled hide, it had short erect ears, eyes starting from their sockets, and its fingers and hand were seizing the corners of its mouth, which they thus seemed to pull open to give freer passage to the water it vomited. (Hardy 274-275)

The architect in Hardy probably relished the opportunity of presenting every grotesque Gothic feature he could summon - and where better, in terms of textual structure than to draw a correspondence between the one "fiend" on the outside and the other lying within, fast asleep? Both the gargoyle and the sleeping Frank Troy, in their different ways, bring about destruction, both are agencies of hazard in Fanny Robin's young, broken life.

Returning to Weatherbury churchyard and our first encounter with Fanny, a gentle encounter which nevertheless leaves Gabriel Oak with a sense of "deep sadness", it transpires that these two solitary souls understand each other from the outset and with the minimum of words. He asks her the way to the Malthouse; she responds by asking if the Buck's Head Inn will still be open so late at night; he promises not to tell a soul that he has met her; she accepts his gift of a shilling and reiterates that he must promise to keep her flight a secret (Hardy 44-46).

However, matters are not quite as simple as this superficial reading shows. Inevitably, the plot does require that all of this takes place but less obviously, the textual structures, the aposiopeses, operate subtextually to activate the flow of sympathy, the compassion that Fanny arouses ${ }^{8}$. This is critically important to Hardy's development of the novel's compassion-allegiance. For, whereas the narrator in the coffin scene makes the unwitting blunder (in terms of editorial censorship) of arousing compassion for the "transgressive" girl, despite ardent attempts at rhetorical distancing and alienation, his efforts in the churchyard scene do succeed in securing the narrative from censure because all signs of compassion are transferred to Oak. This kind of transference of sensory intelligence is 
vital to the ultimate messaging or, rather, to the hermeneutical subversiveness of the text 9. For where Oak can display compassion for Fanny with impunity the narrator is shackled, although, of course, it has to be said that at this point there is little indication of her "fallen" status, only that she is absconding in secret which indicates some kind of minor transgression perhaps but no serious offense. Thus, in a way, Cornhill readers don't require the same level of moral protection as they do in the coffin scene.

Back in the churchyard - Oak, from the very first moment of meeting Fanny - is utterly charmed by the "low and dulcet" tones of her voice. He can't resist trying for more, so, "indirectly to get more of the music," he asks the question, "I'll thank you to tell me if I'm in the way for Warren's Malthouse?" Fanny gives him directions and adds "And do you know - " but then comes to a sudden halt! (Hardy 44) Why? Well, we already know that her night flight is fugitive so it would be understandable for her to hesitate if uncertain about allowing her movements to be broadcast. Nevertheless she senses something sympathetic in Oak's manner and, gaining confidence, she completes her broken phrase by asking whether the Buck's Head Inn would still be open. Oak says he doesn't know, explaining that he's a stranger in the neighbourhood whereupon Fanny starts another sentence and then yet again breaks it off. But by now her intuitive, tentative approaches have aroused a flow of sensitive sympathies in Oak who now passes into the night feeling "himself in the penumbra of a very deep sadness when touching that slight and fragile creature." (Hardy 44)

In textual terms, the effect of the structural aposiopesis, in both cases - Oak's meeting with Bathsheba ("Do you want a shepherd...?"), and now with Fanny - activates events while also effecting a connection and not, as might be logically deduced from the broken utterances, a disconnection between neighbours and strangers. Fieldworkers are lured closer to Oak and Oak, in turn, is lured closer to Fanny. Compassion, in both instances, is the outcome, albeit far more intensely in the latter case. As Oak's fingers had "alighted on the young woman's wrist [...] beating with a throb of tragic intensity" he is reminded of the "same quick, hard beat in the femoral artery of lambs when overdriven" (Hardy 46). It would be hard to match this sensitive association with overdriven lambs -- not only for what lambs symbolise in Western culture (gentleness, meekness, innocence, vulnerability) but also for what they represent in sacral terms: purity and sacrifice.

Leslie Stephen evidently wished for less attention to be paid to Fanny. A good example is the search that Bathsheba instigates for the missing girl which is more fully fleshed out in the holograph manuscript than in the first Cornhill edition. Yet again there were cuts. From their subsequent activities we infer that the household and farm workers had suspected something amiss with Fanny because they drag the local pond presumably with a possible suicide in mind. The final conclusion among the villagers is that she has "run away with the soldiers", according to William Smallbury (Hardy 73), although Oak, for one, doesn't believe this at all: but gossip is gossip and it prevails.

Next comes the pathetic scene outside the barracks. The darkly coloured landscape embodies Fanny's desperate predicament ("dreariness", "darkness", Hardy 74) and the words that surface are "misgiving", "regret" (74), "torpidity" (75), and so on. Then there is the mistaken venue for the church marriage and finally, with the aid of a Newfoundland dog, her horrifying journey, possibly through the stages of latent labour to an eventual death in childbirth. Her last voyage is in her coffin.

The point here is that outcast or not within the inner life of the novel, Fanny Robin is quite clearly beloved of her author. In each and every encounter with the "fallen" girl 
compassion informs the narrative tone, diction, grammatical arrangement and imagery with vivid appeals to the senses. But this is far less in evidence in post-Cornhill editions for as I have shown it was alarmingly obvious, and wholly unacceptable, to Leslie Stephen. In the chapter entitled "Fanny's Revenge" we have noticed the manuscript's tender portrait of the young girl on the brink of womanhood with the stillborn babe in her arms but the picture doesn't end there. Beloved of the author, is also Fanny's baby:

By the dead girl's side, enclosed by one of her arms, was the object of the search:

"A curious frame of Nature's work.

A flow'ret crushéd in the bud,

A nameless piece of Babyhood." (Hardy 259) ${ }^{10}$

An elegy, a lament, a tender eulogy, a tribute of devotion for an illegitimate baby? Hermeneutics encompass not only issues involving the written text but also every single semiotic gesture in the interpretative process. This includes extratextual insertions of this kind. In common with allusions, the extratextual item posits a presupposition that borrowing from a noteworthy source lends authenticity, validation and legitimacy to the concept in view: in this case, the concept presented to the reader is that the death of an illegitimate baby is as worthy of tribute and lament as would be the case with any lawfully-born baby. However, it's doubtful that Hardy's contemporary, mainstream world would have shared this view. Indeed, the convention of burying Fanny's body in the pauper's graveyard - that section of the churchyard reserved for prostitutes and the indigent poor - would have accurately reflected the cultural values of the middle-class readership of the day. ${ }^{11}$

Hardy surely hoped to swing this elegy by Leslie Stephen. Perhaps a reputable poet such as Charles Lamb would lend distinction, honour, integrity to his boundary-breaking portrayal? Perhaps this touch of respectability would avert censorship repercussions? Hardy, after all, was accomplished in the use of allusions which frequently succeed in subverting the status quo where direct narration would serve less well. But his hopes were dashed. "Babyhood" was cut.

The Charles Lamb elegy is followed in the manuscript by a shift of focus. Transferring the perspective - which, demonstrating familiarity with an esteemed poet could only be the author's own - Hardy now gives the vantage point and the thought processes to Bathsheba.

Neatly apparelled in its first and last outfit for earth - a miniature wrapping of white linen - with a face so delicately small in contour and substance that its cheeks and the plump backs of its little fists irresistibly reminded her, excited as she was, of the soft convexity of mushrooms on a dewy morning. (Hardy 259)

Sensory experience informs every aspect of this impression from visualized shape to touch, texture, density, moistness. But the gentle compassion, apparent even in Bathsheba's overwrought state, does not strike an appropriate tone in the eyes of the editor and it is excised.

31 In my final extract from the holograph manuscript chapter entitled "Fanny's Revenge" we encounter some phrases which Stephen did allow into the Cornhill. Hardy's original text reads:

Fanny was framed in by that yellow hair of hers, just as she had slept hundreds of times in this house, with the exception of the fresh colour which had formerly adorned her. There was no longer any room for doubt as to the origin of the curl owned by Troy. She appeared rounder in feature and much younger than she had looked during the latter months of her life. Her hands had acquired a preternatural 
refinement, and a painter in looking upon them might have fancied that at last he had found the fellows of those marvellous hands and fingers which must have served as originals to Bellini. (Hardy 259)

The volume edition retains some aspects of the paragraph that begins:

Fanny was framed in by that yellow hair of hers, just as she had slept hundreds of times in this house, with the exception of the fresh colour which had formerly adorned her.

Needless to say, the affectionate evocation of Fanny's youthful, rounder features and refined hands is not retained, for reasons I need no longer explain. Yet of all Hardy's subversive efforts in this passage, his allusion to the Venetian painter, Giovanni Bellini, is by far the most daring. He writes that Fanny's beautiful, refined hands are reminiscent of "those marvellous hands and fingers which must have served as originals to Bellini". This allusion may escape the hermeneutic exploits of many students today but it would have been familiar enough to his more educated contemporaries and most definitely to Leslie Stephen: Bellini does not survive the blue pencil.

Why? Before disavowing the 39 Articles of the church Stephen had been a committed Evangelical Christian, as was his father before him. It is more than likely that, in common with his contemporaries he would have known Bellini (whose paintings are held in large numbers by the National Gallery) for his renowned theme of Madonna and Child ${ }^{12}$. How could Hardy aspire to anything more subversive than to frame this "fallen woman", this young unmarried mother with her illegitimate baby in the iconic form of Virgin and Child?

\section{BIBLIOGRAPHY}

Hardy, Thomas, Far from the Madding Crowd, ed. Rosemarie Morgan, London: Penguin Classics, 2000.

Olivari, Mariolina, Giovanni Bellini, Florence \& New York: Scala/Riverside, 1990.

Ricard, Matthieu R \& Trinh Xuan Thuan, The Quantum and the Lotus: A Journey to the Frontiers where Science and Buddhism Meet, transl. Ian Monk, New York: Three Rivers Press, 2001.

\section{APPENDIXES}

\section{APPENDIX 1: Save the Girls}

The author of this small extract below is Mason Long and his book is entitled Save the Girls (Fort Wayne: Mason Long, 1883). Mason Long wrote this in 1883 - a decade after Far from the Madding Crowd and a decade before Tess. He is one of those ardent Victorians who set out to save the fallen woman. He writes:

Fallen women owe their ruin to a variety of causes. A large number of them have a natural tendency to vice, which is born in them, being inherited from their 
ancestors. Such are, in thought and feeling, prostitutes from youth, and, at the first opportunity, become profligate, either openly or covertly. Many of them remain chaste in body, owing simply to a lack of opportunity to indulge their natural propensities, but their minds are without purity, their passions and sentiments are coarse, and the sexual sin they crave is just as much theirs as though actually committed in deed, as it is in thought.

But, happily, a majority of impure women are not of this class. [...] They have been led astray from various causes, and having taken the one false step which, according to our code of social ethics, makes a woman forever an outcast, find themselves forced into the paths of sin, which they tread until they fill premature and dishonoured graves. [...] These poor creatures have been deceived and, in a moment of weakness, have been led astray and fallen never to rise again.

This "Save-the-Girls" philanthropic approach was considered admirable at the time. The crux of the matter being that of impurity in both cases - whether born impure or led astray - a fallen woman is forever impure and an outcast.

\section{APPENDIX 2: “On an Infant Dying as Soon as Born", Charles Lamb (1775-1834)}

I saw where in the shroud did lurk

A curious frame of Nature's work;

A flow'ret crushéd in the bud,

A nameless piece of Babyhood,

Was in her cradle-coffin lying;

Extinct, with scarce the sense of dying:

So soon to exchange the imprisoning womb

For darker closets of the tomb!

She did but ope an eye, and put

A clear beam forth, then straight up shut

For the long dark: ne'er more to see

Through glasses of mortality,

Riddle of destiny, who can show

What thy short visit meant, or know

What thy errand here below?

Shall we say, that Nature blind

Check'd her hand, and changed her mind

Just when she had exactly wrought

A finish'd pattern without fault?

Could she flag, or could she tire,

Or lack'd she the Promethean fire

(With her nine moons' long workings sicken'd)

That should thy little limbs have quicken'd?

Limbs so firm, they seem'd to assure

Life of health, and days mature:

Woman's self in miniature!

Limbs so fair, they might supply

(Themselves now but cold imagery)

The sculptor to make Beauty by.

Or did the stern-eyed Fate descry

That babe or mother, one must die;

So in mercy left the stock

And cut the branch; to save the shock

of young years widow'd, and the pain

When Single State comes back again

To the lone man who, reft of wife,

Thenceforward drags a maiméd life? 
The economy of Heaven is dark, And wisest clerks have miss'd the mark Why human buds, like this, should fall, More brief than fly ephemeral That has his day; while shrivell'd crones Stiffen with age to stocks and stones; And crabbed use the conscience sears In sinners of an hundred years. -Mother's prattle, mother's kiss, Baby fond, thou ne'er wilt miss: Rites, which custom does impose, Silver bells, and baby clothes; Coral redder than those lips Which pale death did late eclipse; Music framed for infants' glee, Whistle never tuned for thee; Though thou want'st not, thou shalt have them, Loving hearts were they which gave them.

Let not one be missing; nurse, See them laid upon the hearse of infant slain by doom perverse. Why should kings and nobles have Pictured trophies to their grave, And we, churls, to thee deny Thy pretty toys with thee to lieA more harmless vanity?

\section{NOTES}

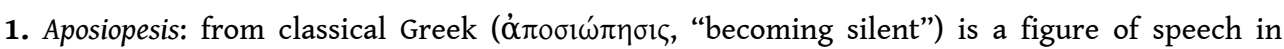
which speech is broken off and left unfinished, the ending to be supplied by the imagination, signifying an unwillingness or inability to continue by becoming overcome with passion (fear, anger, excitement) or modesty.

2. See also Appendix 1. Later in his literary career as his reputation is assured Hardy affords himself this risk. In legal terms, this compromised liaison might require mediation.

3. Stage: a clinical-sounding word meaning a progression of states; existence, a stiff Latinate word pointing to a world that persists quite independently of our senses.

4. Book/volume editions were not subject to the same laws of censorship as were "drawingroom" magazines such as Cornhill-type publications. Magazines and periodicals could be purchased openly on the market stalls, public bookstands in railway stations and so on. Books/ volumes were not. They were distributed by circulating libraries and accessed by subscription only. This marketing method therefore determined what was accessible to the general reading public.

5. Note the euphony of "whispered" suggesting hidden pain forced out on the breath rising to a piteous (long vowel sound of) "wail."

6. Problematic largely because memory plays an important part, almost an unwittingly censorious part in the process: it must override the imagination. This is complicated by the fact that memory and imagination have been shown to affect one another - operating in identical parts of the brain. For Hardy, the struggle to exert memory over imagination succeeds only in each outwitting the other to the detriment of both.

7. Hardy is, as ever, attentive to botanical detail. The alder flourishes near streams and wetlands and is common among the first species to colonise areas disturbed by floods and storms. 
8. As innocuous as these images, in the coffin scene, of innocence and tenderness may seem to us, they appeared, to the editor, as heresies - cultural heresies. A modern-day equivalent might be rape where the young girl is reported as wearing "provocative" garments and is deemed, consequently, neither "innocent" nor deserving of "tenderness".

9. And to elucidate on one point for those of you who are less familiar with the publication politics of the 1870s, when Far From the Madding Crowd first arrived on the scene, what was permitted to the novel's characters was not readily permitted to the narrator. The narrator was expected to rebuke (tonally, imagistically etc) his characters if they stepped out of line: a characteristic device would be "coming to a bad end". Indeed, ideally the narrator would add a censorious note or a countermanding event at the first sign of any moral transgression. Hardy was quick to learn effective counteractive remedies such as employing an alternative narrator (or secondary character) to intervene with what I have called a Grundyan voice, when necessary. of course, when his reputation as a novelist was secured - certainly by the time of Tess and Jude he no longer employed a Grundyan bystander to deliver rebukes and all those belittling asides such as "Women are all such and such..." Interestingly, Oak was praised by critics for performing the Grundyan role where the wayward Bathsheba is concerned.

10. See Appendix 2: "On an Infant Dying as Soon as Born," Charles Lamb (1775-1834). This may be a sentimental if not mawkish poem to the modern ear and sometimes reduces millennium students to mocking laughter. But sentimentality originally indicated a sincere expression of feelings as a guide to truth in contrast to current usage which defines it as an appeal to shallow, uncomplicated emotions at the expense of reason.

11. See also Tess of the d'Urbervilles in which Tess experiences a similar dilemma over the burial of her infant, Sorrow.

12. One critic observes that "Bellini's paintings are characterized by a strange, subtle tension that always binds the mother and child in a relationship of profound pathos" (Olivari 4). See for example one such Madonna and Child presented by the National Gallery of Australia.

\section{ABSTRACTS}

Thomas Hardy's Far from the Madding Crowd failed to satisfy his commissioning editor Leslie Stephen's expectations of a pastoral novel along the lines of Under the Greenwood Tree but was, instead, subjected to rigorous censorship prior to publication in the Cornhill. This essay examines just part of Hardy's creative methodology, his attempts to subvert his own text in keeping with his anti-establishment views, some 20 years before achieving sufficient freedom from the codes and practices of censorship to be able to express them openly in Tess. The focus of this essay is confined to Hardy's treatment of Fanny Robin and the subtextual devices he employs in his efforts to arouse the reader's compassion for the Fallen Woman.

Far from the Madding Crowd ne répondit pas aux attentes de Leslie Stephen, le rédacteur qui avait passé commande d'un roman pastoral dans la veine de Under the Greenwood Tree. Le roman, au contraire, fut soumis à une censure rigoureuse avant d'être publié dans le Cornhill. Cet article étudie en partie la méthodologie créative de Hardy, ses tentatives pour subvertir son propre texte sans renier ses vues contestataires, une vingtaine d'années avant de s'être suffisamment affranchi des codes et pratiques de la censure pour pouvoir exprimer ses vues ouvertement dans Tess of the d'Urbervilles. Cet article se concentre sur le traitement par Hardy de Fanny Robin et sur 
les procédés d'écriture sous-jacents qui lui permettent de faire naître la compassion du lecteur pour la Femme Déchue.

INDEX

Mots-clés: censure, Stephen (Leslie), Cornhill, procédés littéraires, herméneutique, compassion Keywords: censorship, literary devices, hermeneutics

\section{AUTHOR}

\section{ROSEMARIE MORGAN}

Rosemarie Morgan taught at Yale University for 20 years and is President of The Thomas Hardy Association which produces the biannual Hardy Review - the premier scholarly journal in Hardy studies - under her editorship. Numbered among her publications on Hardy are Women and Sexuality in the Novels of Thomas Hardy, The Ashgate Research Companion to Thomas Hardy (ed.) and The Student Companion to Thomas Hardy. 